\title{
The Challenge of American Women's Lifelong Goal to Equality: The Lack of Clout and Influence Continue to Plague Advancement
}

\author{
René Ryman \\ Assistant Professor, American University of Paris, 147 rue de Grenelle, 75007, Paris, FR
}

\begin{abstract}
*Corresponding Author: René Ryman, Assistant Professor, American University of Paris, 147 rue de Grenelle, 75007, Paris, FR
\end{abstract}

\begin{abstract}
In this article, the author addresses the effect of The Equal Pay Act of 1963 and organizational programs that have been changed to help women progress toward wage equality and how these efforts to help women continue to fall short of their goals to assist females in securing leadership and higher job opportunities as well as seek equal wages within what is considered traditional and non-traditional careers.
\end{abstract}

Keywords: The Equal Pay Act of 1963, Women, Wage Disparity, Wage Inequality, Mentor Programs

\section{The ERA OF HoPe FOR WOMEN -THE EFFECT OF LEgislative ACTION IN THE 1960's}

The goal of achieving wage equality has been a long journey for women in the United States and in review of historic data trends, it can be concluded that it will take a few more generations before payrolls no longer reflect income disparity between genders. American women celebrated the historic day when President John F. Kennedy signed "The Equal Pay Act of 1963"on June 10, 1963, a United States labor law amending the Fair Labor Standards Act that aimed to abolish wage disparity based on sex and insure equal wages for women across the nation. This action set the foundation for the era when women would have the opportunity to select their own careers and advance financially alongside their male peers. Yet after more than five decades, the goal of wage equality continues to be a distant, unattainable goal. While some strides have been made to equalize pay for a small percentage of working women, the overall wages for American females tops out at .805 cents relative to each $\$ 1.00$ earned by male workers. As this progression toward closing the wage gap has slowed in recent years due to various economic, social and leadership challenges of the nation, it is expected that equal wages between the sexes will not be achieved until the year 2119, a total of 156 years after the bill was initially signed into law. ${ }^{1}$ Based on the following information, it should be noted that evidence of the benefits intended under the Act for wage equality could not be found for 30 years after the signing of the legislation in 1985 when wage disparity rate decreased slightly from the level in 1955.

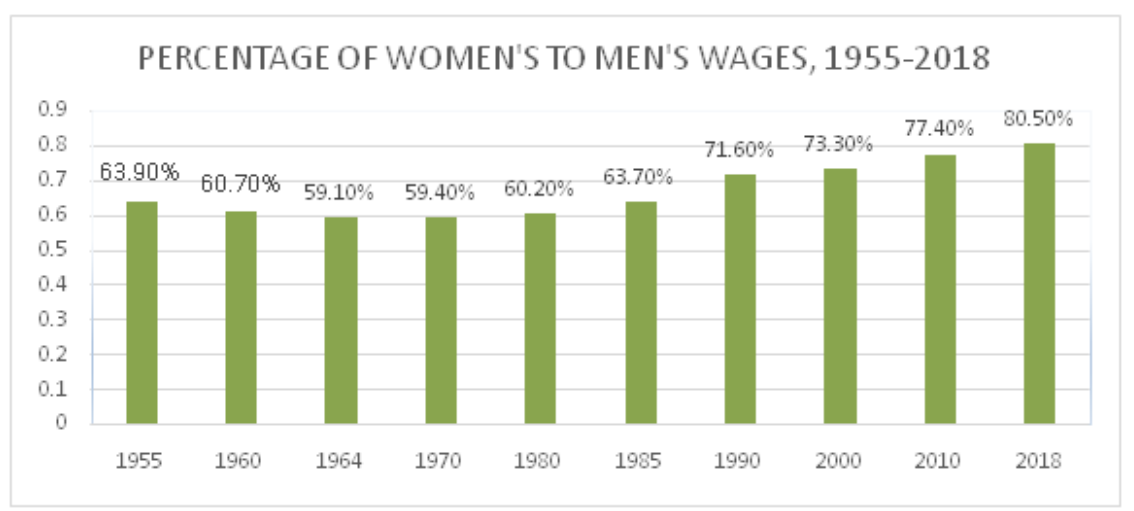

Data Sources: 1. Women's Earnings as a Percentage of Men's, 1951-2013. Retrieved from https://www. infoplease.com/womens-earnings- percentage-mens-1951-2013\& 2. Historic Distribution

\footnotetext{
${ }^{1}$ AAUW (2018). The simple truth about the gender pay gap. Retrieved January 2, 2018 from https://www.aauw. org/research/the-simple-truth-about-the-gender-pay-gap/.
} 
The Challenge of American Women's Lifelong Goal to Equality: The Lack of Clout and Influence Continue to Plague Advancement

Tables (2018 data) https://www.census.gov/data/tables/time-series/demo/income-poverty/historical-incomehouseholds.html

\section{The College Years - The ERA OF HoPe \& DebT}

As the women's movement in the 1960's opened the doors to a wider array of career opportunities, the U.S. higher educational system was poised to support that initiative. Today, more than ever in the history of the United States, women are completing their degrees and establishing themselves in successful careers. Higher educational institutions have welcomed the increase in student enrollments as women have embraced the availability of a higher education as a way to establish a career. According to the U.S. Census Bureau, in 2014, 29.9\% of men completed a bachelor's degree compared to $30.2 \%$ of women. Only a decade earlier, in $2005,28.5 \%$ of men finished a bachelor's degree, while only $26 \%$ of women completed their degree. ${ }^{2}$ To their credit, women have edged out men in the receipt of bachelor degrees and this trend is expected to continue in the future. However, if the prediction of the closing of the wage gap for the sexes will not occur until 2119, women graduating from college are faced with the unfair burden of not only being denied the ability to earn equal wages for the duration of their careers but they are also at a considerable disadvantage as tuition expense and any debt servicing on loans and expense accumulation will be more burdensome to them compared to their male peers.

While many within American society view education for women as the great equalizer between the sexes, the financial price of such opportunity has been substantial for women. In 2018 women held two-thirds of the national student loan debt, nearly $\$ 900$ billion of the $\$ 1.4$ trillion total in student loans. The issue of college selection has contributed to their college expenses as well since twice as many women than men attended more expensive, for-profit online colleges in 2016.The recruitment of women through the offering of flexible programs often confronts the backlash of the value and quality of the degree compared to other traditional brick-and-mortar, highly reputable institutions. ${ }^{3}$ The overall result for women is that they pay more for a degree that is limited in its offerings and credibility compared to other institutions incurring higher debt while earning lower wages due in part to historic wage inequality but compounded by the inferior degree programs offered by less reputable colleges and universities aggressively recruiting more women than men into their programs.

\section{Post College \& Career Advancement}

Although there has been much celebration over the vast number of female students who secure jobs within their selected areas of studies after graduation, it's important to note that in both jobs historically out of reach for women, such as lawyers and doctors, as well as positions that are considered traditionally female, such as nursing and education, there has not been wage equality, therefore continuing to undervalue the contributions women have made in both traditional and nontraditional venues. The following chart represents wages within ten occupations where women have the highest loss of annual earnings.

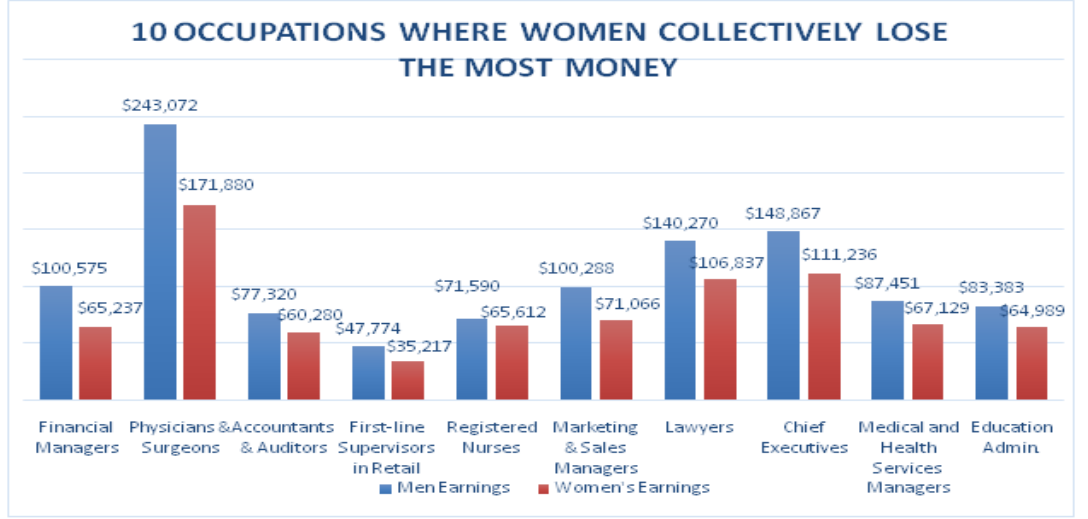

Source: What is the gender pay gap in your state? (2018) AAUW. Retrieved January 2, 2019 from https:// www.aauw.org/research/the-simple-truth-about-the-gender-pay-gap/

${ }^{2}$ Feeley, N. (2015). Women are now more likely to have college degree than men. Time. Retrieved January 2, 2018 from http://time.com/4064665/women-college-degree/.

${ }^{3}$ Piper, J. \& Hammond, R. (2018). Student debt is worse for women. Retrieved December 13, 2018 from https://www.chronicle.com/article/Student-Debt-Is-Worse-for/244145. 
Today, U.S. corporations across the nation have invested heavily in programs to promote women arriving with their newly minted degrees, seeking positions that offer opportunities for advancement. These companies, armed with carefully crafted organizational policies and mission statements ensuring non-discrimination and fairness to individuals regardless of race and gender, offer the promise of higher paying jobs and higher salary grades to hard working women. Such highly touted public campaigns paint a believable and attainable goal for women from the perspective of professional development and economic prosperity. However, the actual results of such programs have fallen short of these promising initiatives. A popular program that offers both men and women guidance in becoming recognized and considered for promotion is through internal company mentoring and networking programs, which are designed to address individual traits and talents for improvement in an effort to groom candidates for career advancements. However, the outcome of such efforts has led to men continuing to be promoted more than women. One factor can be tied to the type of mentors that are assigned to women. Women, more than men, are mentored by non-manager employees or first-level managers within an organization, compared to men who are commonly mentored by senior executive-level employees. Therefore, the level of clout in support of promotional recommendations is favored toward male candidates based on their own mentor's level of organizational clout as higher ranking employees holding more influence over promotion decisions compared to lower level employees mentoring women. Overall, while both men and women may receive support and guidance from mentoring relationships, between 2008 and 2010, 73\% of men received one or more promotions, compared to with $65 \%$ of women receiving promotions. ${ }^{4}$

For women seeking higher ranks within organizations, the journey continues to be more challenging compared to their male peers. According to the Fortune 500list (2016), the number of female CEOs actually dropped to 21 from 24 in 2015, thereby leaving women in these top ranked positions at only $4.2 \%$ of America's biggest corporations. Furthermore, job stability for the few women who do reach such levels within an organization is less sustainable long term as females are more likely to lose their jobs compared to their male counterparts. Over the past decade $27 \%$ of men lost their CEO positions because they were fired compared to $38 \%$ of women who were forced to leave their positions. ${ }^{5}$ Even if women succeed within an organization and overcome the limited opportunities provided to them, there is still a higher chance that they will not progress long term within the higher ranks of management.

\section{RETIREMENT AND FINANCIAL INSECURITY}

After a lifelong of work and the stress of financial obligations, the golden years of retirement is often viewed as the final reward for well-earned time to spend on personal activities - instead of those that are professional. As American society has embraced the time when older adults can commit to a less stressful daily routine, the reality is that many retirees will simply exchange the stress of a lower paying job for that of retirement that lacks a sustainable amount of cash. The financial uncertainly for women in retirement is even more threatening to their economic sustainability because after enduring years of lower wages, they will have to manage higher medical bills than men as they enter retirement. As the charts below show, in 2002 after subtracting medical bills from social security benefits, men retained residual money in the amount of $\$ 3225.00$ of their social security payments compared to women (32\%), and during 2004 and 2012 retained $\$ 3386.00$ and $\$ 4111.00$ more than women respectively. According to data from the U.S. Census Bureau collected from the non-profit organization, Wider Opportunities for Women, the majority of women in the U.S. are unable to cover their basic living expenses, and the percentage of those in distress is $50 \%$ higher than men. ${ }^{6}$ With rising cost of health care and declining coverage, it can be expected that higher medical bills for women will certainly contribute to increased poverty levels in the future.

\footnotetext{
${ }^{4}$ Carter, N., Ibarra H. \& Silva, C. (2010). Why men still get more promotions than women. Harvard Business Review. Retrieved December 1, 2018 from https://hbr.org/2010/09/why-men-still-get-more-promotions-thanwomen.

${ }^{5}$ Nagy, R. (2014) Women are in more danger of being fired than men. Retrieved December 13, 2018 from https://www.thebusinesswomanmedia.com/danger-of-being-fired/

${ }^{6}$ Bennetts, L. (2012) Census data reveals elder women's poverty crisis. Retrieved December 20, 2018 from https://www.thedailybeast.com/census-data-reveals-elder-womens-poverty-crisis?ref=scroll.
} 
The Challenge of American Women's Lifelong Goal to Equality: The Lack of Clout and Influence Continue to Plague Advancement

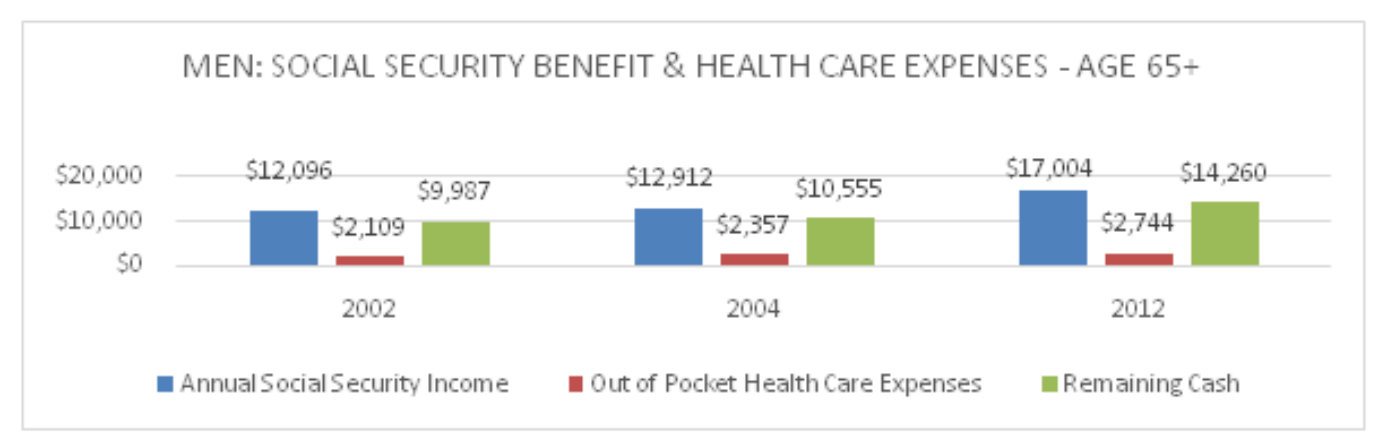

Source: Social Security Earnings Info: Retrieved on January 2, 2018 from https://www.infoplease.com/ business -finance/us-economy-and-federal-budget/average-monthly-social-security-benefits-1940-2015.

Out of Pocket Medical Expenses. Retrieved on January 2, 2018 from https://www.cms.gov/Research-Statistics-Dataand-Systems/Statistics-Trends-and-Reports/NationalHealthExpendData/Downloads/2010GenderandAge Tables.pdf.

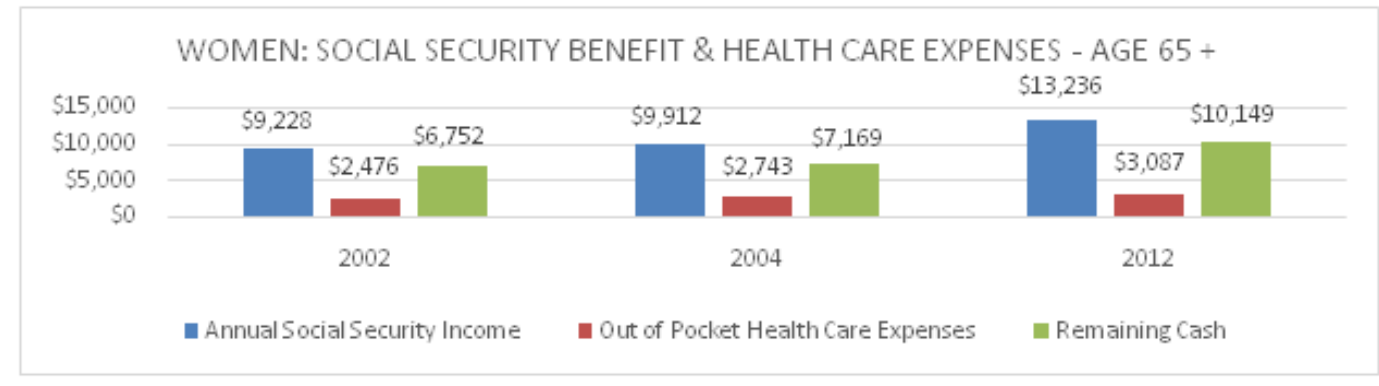

Source: Social Security Earnings Info: Retrieved on January 2, 2018 from https://www.infoplease.com/ business-finance/us-economy-and-federal-budget/average-monthly-social-security-benefits-1940-2015.

Out of Pocket Medical Expenses. Retrieved on January 2, 2018 from https://www.cms.gov/ResearchStatistics-Data-and-Systems/Statistics-Trends-and-Reports/NationalHealthExpendData/Downloads/ 2010 GenderandAgeTables.pdf.

\section{The NeEd FOR MORE ORganizational INFLUENCE AND LEADERSHIP ClouT}

In conclusion, we have witnessed decades of the women's movement pushing for equality, engaging in political action initiatives that take aim at the current inequality continuing to plague American society and, more recently, ongoing social media posts heightening awareness of abuses and discrimination against women on both social and political levels. The number of demonstrations supporting women has grown significantly since the 2016 U.S. Presidential election to levels that include involvement from people around the world who support the path toward equality for their family members and friends. However, there is still a long way to go before equality for women becomes a social norm whereby such public displays of outcry will no longer be needed. The solution to the current discrimination against women must come in the form of a greater level of support within government and organizations. It can be concluded that simply changing legislation and raising awareness of the need for equality has not produced significant results. It can be argued that there must be an increase in sustainable influence before such change may occur. But how is that influence achieved in today's modern world of promising women who are eager to gain entrance into a career of her choice while being treated equally to her male peers?

In an effort to identify a solution we first have to first acknowledge that women are not a minority. By merely population numbers, women have a slight edge on men with a ratio of $51 \%$ to $49 \%$ respectively. Second, understanding that women are a minority within the context of influence and clout, what is needed is to increase their participation in higher level organizational positions in both the public and private sectors. This status begs the question, with a large population combined with laws and policies in place to help them, at what point does a social minority actually have enough influence to establish sustainable change? Moreover, at what point does a minority create enough change such that their views become widely accepted by the population?

According to Dr. Damon Centola, Associate Professor at the Annenberg School for Communication and the School of Engineering and Applied Sciences at the University of Pennsylvania, studies have 
revealed a range of between $10 \%$ and $40 \%$ before minority representation can actually create a shift toward broader views within a population. In his research, Dr. Centola concluded that with the correct engagement of group-wide interactions by a committed minority attempting to overturn an established convention by advancing novel alternatives, the minority size required to bring about change is from $15 \%$ to $35 \%$ with a median threshold of $25 \%$.In conclusion, his research revealed that minority groups less than $25 \%$ could only sway on the average $6 \%$ of the remaining population, and larger minority groups could persuade $72 \%$ to $100 \%$ of the population to adopt a new alternative. ${ }^{7}$ If we apply these percentages to women who have authority within their higher ranks, but lack influence because they are out-numbered by their male peers, we can assume the move toward cultural change is tied to the percentage of women within a particular industry or organization whereby their level of position in the company needs to exceed $25 \%$ before a shift toward equality for women can take place. Simply allowing a few women to hold higher titles as an outward manifestation of gender posturing and recognition of gender equality is insufficient to initiate organizational change. The move toward equality for women has to be done on an individual organizational level that supports growth in the ranks of women in higher positions. The change of a cultural norm is not something that can be legislated as we have seen with the ineffectiveness of such law changes in the past. The key for success is for women to reach the tipping point within an organization through the collaboration of a larger percentage of equal level peers that can actively influence progressive change for the advancement of women.

Citation: René Ryman. “The Challenge of American Women's Lifelong Goal to Equality: The Lack of Clout and Influence Continue to Plague Advancement International Journal of Humanities Social Sciences and Education (IJHSSE), vol 6, no. 3, 2019, pp. 1-5. doi: http://dx.doi.org/10.204 31/2349-0381.0603001.

Copyright: (C) 2019 Authors. This is an open-access article distributed under the terms of the Creative Commons Attribution License, which permits unrestricted use, distribution, and reproduction in any medium, provided the original author and source are credited.

${ }^{7}$ Centola, D. (2018) At what size does a minority group become influential? American Associate for the Advancement of Science. Retrieved January 3, 2018 from https://www.eurekalert.org/pub_releases/2018-06/ aaft-aws060418.php. 